\title{
JUDICIAL DECISION-MAKING AND TRANSNATIONAL LAW: A SURVEY OF COMMON LAW SUPREME COURT JUDGES
}

\author{
Brian Flanagan* and SinÉAd Ahern**
}

\begin{abstract}
This is a survey study of 43 judges from the British House of Lords, the Caribbean Court of Justice, the High Court of Australia, the Constitutional Court of South Africa, and the Supreme Courts of Ireland, India, Israel, Canada, New Zealand and the United States on the use of foreign law in constitutional rights cases. We find that the conception of apex judges citing foreign law as a source of persuasive authority (associated with Anne-Marie Slaughter, Vicki Jackson and Chris McCrudden) is of limited application. Citational opportunism and the aspiration to membership of an emerging international 'guild' appear to be equally important strands in judicial attitudes towards foreign law. We argue that their presence is at odds with Ronald Dworkin's theory of legal objectivity, and is revealed in a manner meeting his own methodological standard for attitudinal research.
\end{abstract}

Wordsworth's words, written about the French Revolution, will, I hope, still ring true: Bliss was it in that dawn to be alive. But to be young was very heaven.

- Justice Stephen Breyer's assessment of 'the global legal enterprise now upon us' before the American Society of International Law (2003)

\section{INTRODUCTION}

The attitudes of senior judges have long been a focus of empirical study in the United States. Elsewhere in the common law world, attention has been more sporadic - due in part to a lack of interest among political scientists and to the concentration of the socio-legal movement on frontline actors, rather than those at appellate level. Nevertheless, decision-making in apex common law courts on matters of constitutional rights is increasingly the object of general hypothesis. The surge in interest is largely the product of the growth in prominence of transnational comparison as a mode of argument in such cases. Seeking to explain this discursive phenomenon, some legal thinkers and

\footnotetext{
* Lecturer in Law, National University of Ireland, Maynooth. Too many people helped bring this project to fruition than can be named here, not least the participants themselves. But we must mention Chris McCrudden, Liora Lazarus, Ewan McKendrick, Brenda Hale, Colin Scott, John O'Dowd, Ian Plummer, and the late Tom Bingham.

** $\mathrm{PhD}$ candidate, University of Limerick.
} 
political scientists have characterized it as a global project or jurisprudence. Several broadly comparable theories have been proposed, which we shall label the 'globalist' school. ${ }^{1}$ These theories characterize the phenomenon as both a cause and reflection of increased peer consciousness amongst apex judges, a common judicial mission of individual/minority protection, and an enhanced sensitivity toward the possibilities of 'persuasive authority'. ${ }^{2}$ Some judges have publicly commented on the use of comparison in constitutional rights cases, thereby providing a range of primary material on what is exactly taking place. Yet while such remarks and reported conversations are helpful in formulating hypotheses about the phenomenon, they are of relatively limited value in testing them.

The transnationalization of constitutional argument raises a number of questions. Normatively, there is the issue of the legitimacy of the use of foreign law in the resolution of disputes about individuals' constitutional rights. Following the recent citation of foreign law by the US Supreme Court in two

${ }^{1}$ Eg, V Jackson, Constitutional Engagement in a Transnational Era (OUP, New York, 2009); V Jackson, 'Transnational Discourse, Relational Authority, and the US Court: Gender Equality' (2003) 37 Loy LA L Rev 271; C McCrudden, 'Judicial Comparativism and Human Rights' in E Örücü and D Nelken (eds), Comparative Law: A Handbook (Hart, Oxford, 2007) 371; C McCrudden, 'A Common Law of Human Rights?: Transnational Judicial Conversations on Human Rights' (2000) 20 Ox J Legal Stud 499; A-M Slaughter, A New World Order (Princeton University Press, Princeton, 2004) 66-100; A-M Slaughter, 'A Typology of Transjudicial Communication' (1994) 29 U Richmond L Rev 99, 124-125; R Teitel, 'Comparative Constitutional Law in a Global Age' (2004) 117 Harv L Rev 2570; C Scott and P Alston, 'Adjudicating Constitutional Priorities in a Transnational Context: A Comment on Soobramoney's Legacy and Grootboom's Promise' (2000) 16 South African J Human Rts 206; C L'Heureux-Dubé (formerly of the Supreme Court of Canada), 'The Importance of Dialogue: Globalization and the International Impact of the Rehnquist Court' (1999) 34 Tulsa L J 15. (McCrudden's analysis is distinctive in its agnosticism on the question of whether current judicial 'globalization' is in fact a positive development for the protection of human rights). Globalist theory has begun to inspire a secondary literature; see eg, J Habermas, 'Interpreting the Fall of a Monument' (2003) 4 German L J 701, 707-708 (urging greater judicial and other reciprocity to advance cosmopolitanism); J Goldsworthy, 'Introduction' in Goldsworthy (ed), Interpreting Constitutions: A Comparative Study (OUP, New York, 2006) 3, 'We live in an era of "cosmopolitan constitutionalism" in which lawyers and judges increasingly look beyond their own borders and borrow ideas from other jurisdictions. The time is ripe for a comparative study of the methods by which constitutions have been interpreted.'

${ }^{2}$ Globalist theory takes as its starting point Patrick Glenn's view that persuasive authority is 'authority which attracts adherence as opposed to obliging it.' P Glenn, 'Persuasive Authority' (1987) 32 McGill L J 261, 263. See Slaughter ibid (1994) 124-125; Jackson (2003) 287-288; and McCrudden (n 1) (2000) 503 (citing Glenn). Comparable views are expressed in Craig and Alston ibid 217; L'Heureux-Dubé ibid 16-17 and Teitel ibid 2593-2594. This understanding of persuasive authority is foreshadowed in both Hart and Dworkin's theories of law; HLA Hart, The Concept of Law (OUP, Oxford, 1961) 294, 'Where [the judge] considers that no statute or other formal source of law determines the case before him, he may base his decision on e.g., a text of the Digest, or the writings of a French jurist... The legal system does not require him to use these sources, but... they are recognized as "good reasons" for decisions.'; R Dworkin, Law's Empire (Bellknap Press, Harvard University, Cambridge, 1986) 25, 'The relaxed doctrine of precedent... demands only that a judge give some weight to past decisions on the same issue... This relaxed doctrine may embrace the past decisions not only of courts above him or at the same level in his jurisdiction but of courts in other states or countries.' 
major rights decisions, ${ }^{3}$ a controversy over the practice re-ignited-one steeped in the terminology and claims of globalist theory. A storm of debate within American academia on the merits and practice of judicial comparison ${ }^{4}$ was joined by a political debate in which leading politicians railed against the Court's apparent reliance on foreign law. ${ }^{5}$ Outside the US, the gauntlet was taken up by judges and theorists sympathetic to comparative legal argument. ${ }^{6}$ For now it seems the storm has passed, leaving behind a wealth of material on the propriety of resorting to foreign law in domestic adjudication.

Answering the question of legitimacy requires more than providing a good justification in principle. It all depends on the status attributed to foreign law by comparing judges - even the most sophisticated defence of judicial comparison will fail if judges compare for unrelated ends. Consider globalism's 'dialogical' narrative of apex judging:

[C]onstitutional law can be understood as a site of engagement between domestic law and international or foreign legal sources and practices... Transnational sources are seen as interlocutors, offering a way of testing understanding of one's own traditions and possibilities by examining them in the reflection of others. ${ }^{7}$

${ }^{3}$ Lawrence $v$ Texas 539 US 558 (2003) (concerning the individual's right to engage in consensual homosexual relations) and Roper v Simmons 543 US 551 (2005) (concerning the individual's right to escape cruel and unusual punishments for his crimes).

${ }^{4}$ For a list of some of the many contributions, see E Benvenisti, 'Reclaiming Democracy: The Strategic Uses of Foreign and International Law by National Courts' (2008) 102 AJIL 241, fn 1.

${ }^{5}$ See eg, Reaffirming American Independence Resolution, HR Res 97, 109th Cong. § 2 (2005). Hostility toward the use of foreign law was similarly expressed at Elena Kagan's recent Supreme Court nomination hearing; see eg, Sen. J Kyl, 'I am troubled by [Kagan's response] because it suggests that you could turn to foreign law to get good ideas.' < http://www.c-span.org/Special/ Supreme-Court-Kagan-Senate-Confirmation-Hearing-34896.aspx $>$ (17.50 mins).

Legal prohibitions of comparison are not unprecedented; see A Watson, 'Legal Change: Sources of Law and Legal Culture (1983) 131 U Pa L Rev 1121, n 109 (citing the Leggi e constituzioni of 1770 of Sardinia and Piedmont which banned recourse to the law of a neighbouring place.) Neither, incidentally, is executive enthusiasm for judicial comparison; 'In France the stamp of official recognition to the value of comparative law was first accorded as far back as 1876 when a committee attached to the French Ministry of Justice was created, whose main purpose was to inform judges about foreign law.' WJ Kamba, 'Comparative Law: A Theoretical Framework' (1974) 23 ICLQ 485, 498.

${ }^{6}$ Eg, B Markesinis and J Fedtke, 'The Judge as Comparatist' (2005) 80 Tulane L R 11; (Australian Justice) M Kirby, 'International Law-The Impact of National Constitutions' (March 30 2005) American Society of International Law Grotius Lecture, delivered in Washington, DC. Full transcript of the lecture available at http://www.hcourt.gov.au/speeches/kirbyj/kirbyj 30mar05.html accessed on August 9, 2010; (South African Justice) S Kentridge, 'Comparative Law in Constitutional Adjudication: The South African Experience' 80 (2005) Tulane L R 245; (South African Justice) L Ackermann, 'Constitutional Comparativism in South Africa: A Response to Sir Basil Markesinis and Jörg Fedtke' (2005) 80 Tulane L Rev 169; Lords Bingham and Hoffman, 'Unreliable Evidence' BBC Radio 4 (30 May 2006); (Irish Chief Justice) J Murray, 'New England School of Law Commencement Address 2006-07' (2007) 41 New England Law Review 247.

7 V Jackson, 'Constitutional Comparisons: Convergence, Resistance, Engagement' (2006) 119 Harv L Rev 109, 114. Jackson refers to Sujit Choudhry's elaboration of a concept of dialogical constitutional comparison in Choudhry, 'Globalization in search of Justification: Toward a 
As the focus of attempts to both explain and justify the use of foreign law in constitutional discourse, the attitudes of apex judges are clearly at issue. This study aims to shed light on how common law judges view foreign law as a source of argument in constitutional rights matters, how they 'see' transnational sources. ${ }^{8}$ Its data provide the basis for preliminary testing of globalist theory. More generally, they bring a practical insight to bear on jurisprudential debates invoking the nature of judicial reasoning in appellate courts.

To investigate the character of transnational comparison as a mode of legal argument, we must identify the materials it purports to invoke. Debates about the legitimacy of judicial comparison are most concerned with the use of certain kinds of transnational materials. Comparison to such materials would accordingly seem to constitute a more or less distinct form of legal argument. Thus, from the domestic perspective, transnational legal material concerning individual rights appears to take two forms, the norms of binding public international law, and legal norms of other countries and other groups of countries. The domestic status of these materials appears to be subtlety different; a judge's use of the former in determining an individual's rights can seem more transparently appropriate (or less transparently inappropriate) than their use of the latter. Chris McCrudden has sought to capture the apparent contrast by way of a formal distinction between binding and non-binding transnational norms. ${ }^{9}$ On this account, the use of transnational material to establish what law is binding on the domestic jurisdiction is different (and less potentially problematic) to using such material absent binding international legal commitments.

McCrudden's distinction is inadequate for our purposes however. First, it is unclear whether it can explain the apparent contrast in the materials' legal status. Presumably, if the consensus of some set of countries is evidence of the soundness of a favoured legal conclusion, it will equally be evidence of the unsoundness of a favoured conclusion. If so, attention to the views of those countries when adopting legal conclusions is not straightforwardly 'optional'. Indeed, what exactly it is to be binding is a large part of the debate on the appropriateness of judicial comparison. ${ }^{10}$ Second, in the context of the ongoing debate about the status actually attributed to transnational legal materials by domestic judges, differentiating that material in terms of what is

Theory of Comparative Constitutional Interpretation' (1999) 74 Ind L J 819. For globalists, the upshot of the use of comparative material as 'a means to stimulate constitutional self-reflection' (Choudhry, 892) is that it has 'persuasive' value - the potential to persuade both the judge and his audience of the appropriateness of a particular solution.

${ }^{8}$ We include the United States, India, Israel and South Africa as common law jurisdictions.

9 McCrudden (n 1) (2007) 371, 379.

${ }^{10}$ See eg, V Jackson (2003) 302-318; M Tushnet, 'When Is Knowing Less Better Than Knowing More? Unpacking the Controversy over Supreme Court Reference to Non-US Law' 90 Minn L Rev 1275 (2006), 1284-86; M Moran, 'Authority, Influence, and Persuasion: Baker, Charter Values and the Puzzle of Method' in D Dyzenhaus (ed), The Unity of Public Law (Hart, Oxford and Portland, 2004) 389. 
binding risks begging the question of judicial perception. ${ }^{11}$ Conversely, ignoring the apparent contrast in status is liable to conflate argumentatively distinct practices of legal comparison. ${ }^{12}$ What would help is a property considered characteristic of the form of comparative argument central to current debates about transnationalized constitutional discourse.

Our focus is on the use of transnational material where the home State's actions convey no intention that the legal question be answered with reference to such material. ${ }^{13}$ Thus, in determining the domestic position on excessive punishment, an Irish court's reliance on either American Eighth Amendment norms or on customary international law seems to lack any claim to be an implementation of the State's manifest intentions. Given the absence of official Irish action indicating an interest in determining Irish punishment norms by reference to either the Eighth Amendment or customary international law, the Irish judge is not simply acting according to the apparent intentions of other branches of government when invoking such material. On the other hand, Ireland's ratification of a treaty concerning punishment which nominates the European Court of Human Rights as the authoritative interpreter thereof suggests an intention that the country's punishment norms be exposed to the jurisprudence of that court. An Irish court's reliance on ECHR jurisprudence would thus have some claim to be in keeping with the actions of the Irish State. ${ }^{14}$

We can also apply this distinction to the use of the laws of other nations for the purpose of determining the meaning of a treaty agreed between those nations. For instance, where a State enters into a treaty with respect to the regulation of air traffic, we may assume that an important part of its reasons for doing so is the belief that there is an advantage in regulating air traffic in

\footnotetext{
${ }^{11}$ For speculation at odds with McCrudden's distinction, see eg, R Bahdi, 'Globalization of Judgment: Transjudicialism and the Five Faces of International Law in Domestic Courts’ (2002) 34 Geo Wash Int'l L Rev 555, 588, 'The failure to distinguish between international and comparative law [apex courts' occasional bundling together of international and comparative sources] stems from the fact that judges look to these sources for their persuasive value and not out of a misguided conviction that the norms in question are binding'; $\mathrm{K}$ Knop, 'Here and There: International Law in Domestic Courts' (2000) 32 NYU J Int'l L \& Pol 501, 525 'Whatever its limitations, a key insight of the transjudicial model of international law in domestic courts is the blurring of international law into comparative law.'

12 Compare E Posner and C Sunstein, 'The Law of Other States' (2006) 59 Stan L Rev 131 fn 30 .

${ }^{13}$ Unusually, art 39 of the 1996 South African Constitution states that, "When interpreting the Bill of Rights, a court, tribunal or forum... may consider foreign law.' Having been given such permission, however, a judge must decide for herself that the resolution of a particular case ought to involve consideration of foreign law.

${ }^{14}$ This is not to say, of course, that the ECHR would necessarily find itself more frequently cited than all foreign jurisdictions. As Bruce Carolan notes, in the Irish case, the US Supreme Court is more often the focus; 'The Search for Coherence in the Use of Foreign Court Judgments by the Supreme Court of Ireland' (2004) 12 Tulsa J Comp \& Int'1 L 123. The point is just that, all things being equal, the fact that, 'Ireland is not a party to and played no role in the adoption of foreign national law' makes the 'constitutional argument' for its citation relatively less compelling than that regarding the ECHR; Carolan 129.
} 
the same manner as other nations, even where that manner is not intrinsically better than all others. Thus, a court's citation of the interpretation given to the treaty by another contracting party will accord with the apparent intentions of the (home) State. Generalizing, we can say that where joining a treaty holds economy of scale or coordination incentives, moves tending to bring the State's domestic law into line with that of other parties follow from the State's ostensible intentions in joining the treaty. ${ }^{15}$ Conversely, where a treaty holds no evident economy of scale or coordination incentive, judicial reliance on the interpretations given to it by other parties would not so follow. ${ }^{16}$ Treaties concerning individual rights appear to fall predominantly into this category. ${ }^{17}$ Accordingly, a State's joining of rights instruments such as the ECHR or the American Convention on Human Rights does not itself appear to manifest an interest in tracking the instrument's treatment within other contracting parties. $^{18}$

In a home State's failure to manifest an intention that the legal question be resolved by reference to a given transnational legal material, we appear to have a property characteristic of the form of comparative legal argument central to current debates about transnationalized constitutional discourse. For our purposes then, a judge uses 'foreign law' when his State's actions fail to convey the intention that the legal question be answered with reference to the transnational material employed. Thus, our focus is on judicial regard to the (domestic and international) laws of other nations when settling domestic rights issues. Such regard may occur in the process of determining the application of a domestic norm, or in determining the impact of a ratified treaty norm on domestic rights, eg, in interpreting one's ECHR commitments by reference to Canadian Court's Charter of Fundamental Rights jurisprudence.

15 Recall the European Court's attention to attributing such qualities to the EC Treaty in its foundational Van Gend en Loos (26/1962) decision, 'The objective of the EEC Treaty, which is to establish a common market, the functioning of which is of direct concern to interested parties in the Community, implies that this Treaty is more than an agreement which merely creates mutual obligations between the contracting states... the task assigned to the Court of Justice under art 177 , the object of which is to secure uniform interpretation of the Treaty by national courts and tribunals.'

${ }^{16}$ For discussion of this distinction, see General Report of the XIVth International Congress of Comparative Law in U Drobnig and S van Erp (eds), The Use of Comparative Law by Courts (Wolters Kluwer, Leiden, 1999) 16 (distinguishing between the 'voluntariness' of judicial recourse to non-domestic material in the interpretation of international agreements for which uniformity is desirable and recourse to such material where uniformity is not a concern).

17 See eg, the US Military Commissions Act (2006), s 6(a)(2) of which states that, when interpreting the country's obligations under the Geneva Convention with respect to armed conflict not of an international character, '[n]o foreign or international source of law shall supply a basis for a rule of decision in the courts of the United States'.

18 International refugee law seems an exception; it both concerns the rights of individuals and holds evident coordination incentives. Hélène Lambert has recently published a citation study of British and French judiciaries' use of foreign law in this field; Lambert, 'Transnational Judicial Dialogue, Harmonization and the Common European Asylum System' (2009) 58 ICLQ 519 (finding much more frequent reference to the law of other nations by British Courts). 
II. METHOD

As the title of the article suggests, we conducted a survey of common law judges working at the apex of their domestic hierarchy on their attitude towards the use of foreign law. ${ }^{19}$ The validity of reliance on judicial selfreporting has been questioned:

[A]sking someone to identify his or her motive is one of the worst methods of measuring motive. People often do not know, or cannot articulate, why they act as they do. In other situations, they refuse to tell, and in still others, they are strategic both in acting and in answering the scholar's question. This is obvious from the example of asking justices about how they reach decisions. . ${ }^{20}$

Epstein and King have two problems in mind here. The second is straightforward; deliberate deception. We think this problem is satisfactorily addressed by a convincing guarantee of confidentiality that extends as far as the subject's institutional affiliation. Combined with the jurisdictional nonspecificity of any criticisms or recommendations with which the study might possibly conclude, ${ }^{21}$ the guarantee seems to remove much of the incentive for deliberate deception.

The first problem - that judges have no reliable means of telling how they reach decisions - is more insidious. But there is a distinction in the kinds of questions that may be asked about judicial decision-making. Epstein and King note studies suggesting that we cannot report our cognitive processes on the basis of true introspection; ${ }^{22}$ that is, that we cannot give non-incidentally accurate accounts of why we reached particular decisions. This concern is certainly relevant to surveying a judge on his motivation for reaching a particular judgment. But studies of that sort seem otherwise unappealing, prohibitively so. In jurisdictions where judges publish judicial opinions,

\footnotetext{
19 The judicial survey seems to have found its initial advocate in T Becker, 'Surveys and Judiciaries, or Who's Afraid of the Purple Curtain?' (1966) 1 L \& Soc Rev 133, 143, 'Judges are reasonable, well-meaning men. The Inquiry is reasonable and well-meant. These great assets should be exploited in research on the judicial process.'

${ }^{20}$ L Epstein and G King, 'The Rules of Inference' (2002) 69 U Chi L Rev 1, 93. See also J Segal and H Spaeth, 'The Authors Respond' (1994) 4 Law and Courts 3, 16, 'Self-deception, social desirability effects, and flatout lying would mar any such analysis. Judicial nominees who can state under oath before the entire nation that they had never thought about Roe $v$ Wade can hardly be fruitful candidates for traditional survey measures.' There is a neat parallel between the dismissal of what judges say they do by law-and-courts scholars and by Ronald Dworkin; see below, 'Implications for the Theory of Legal Reasoning?'.

${ }^{21}$ See Epstein and King ibid 93-94, criticizing N Miller's paper, 'An Empirical Study of Forum Choices in Removal Cases under Diversity and Federal Question Jurisdiction' (1992) 41 Am U L Rev 369 as suffering 'from the problem that attorneys may have incentives to hide their sincere preferences from a researcher they know will make policy recommendations about the need for concurrent jurisdiction.'

${ }^{22}$ R Nisbett and T Wilson, 'Telling More than We Know: Verbal Reports of Mental Processes' (1977) 84 Psych Rev 231 and W Rahn, J Krosnick and M Breuning, 'Rationalization and Derivation Processes in Survey Studies of Political Candidate Evaluation' (1994) 38 Am J Polit Sci 582.
} 
asking them why they reached a particular decision appears pointless. Either a judge has already revealed how they reached it, is unable to, or has something to hide, in which case they will hardly reveal it to someone who wants to publish why, in fact, they voted the way they did.

On the other hand, asking a judge what he thinks is important, how he feels toward X, or what would justify something, is not asking him about his cognitive processes. Yet the answers to such questions advance efforts to explain judicial behaviour merely if judges are more likely to think in accordance with their views and dispositions than not. This is prima facie plausible. Of our 25 questions, just three-3A, 5A and 19-ask judges questions of a causal nature: to identify why they feel or do something. It may be that these questions are likely only to reveal a respondent's pre-existing causal theories about what would plausibly produce the feeling or act in question ${ }^{23}$ or those reasons that sound most rational and systematic. ${ }^{24}$ But, as with the survey's non-causal questions, knowledge that a judge has a particular theory of what causes X seems at least a prima facie basis for taking them to reason accordingly.

Nonetheless, a moderate version of the introspection problem does affect the study: asked which characterization of $\mathrm{X}$ is appropriate, a judge may feel compelled to characterize $\mathrm{X}$ in a particular way simply because that characterization would seem most acceptable to most people. By its nature, however, the potential for this kind of bias tends to be conspicuous, with the result that attentive interpretation can aim to account for it. If a presented characterization seems culturally more acceptable than the others, or vice versa, we may explicitly factor the likely distortive effect into our interpretation of the data. In this way, it is possible to control for obvious introspection bias.

Notwithstanding its stated limitations, we believe that, as a method of investigating judicial decision-making, asking those with actual experience thereof offers unique advantages. Indeed, we would respectfully suggest that the fundamentals of contemporary 'law and courts' scholarship are more likely to be advanced by judicial survey than by constructing more sophisticated proxies for non-legal reasoning and measuring their correspondence with judges' votes. Until we settle on what law is, we cannot control for

23 Per Nisbett and Wilson ibid 248-249. Note the ambivalence in Nisbett and Wilson's commitment to the idea that the causes of our judgments are not identified by direct introspective awareness; 'The present analysis corresponds to common sense in that it allows that we will often be right about the causes of our judgments and behavior'; 253. They give an example of someone correctly identifying the reason for his judgment that he dislikes a stranger who struck him. But if we have reason to think that people report common sense examples like this correctly, it must be that their folk theories of what causes judgment Y reliably predict Y. Since the holders of such theories adopted them thinking them reliable, they are not incidentally correct in believing they will give judgment $Y$ on the occurrence of X. Significantly, the ambivalence is similarly apparent in the authors' explanation of the correspondence between how we think we will reason professionally and how we in fact reason professionally; 254.

24 Rahn et al (n 22) 584-585. 
whether a judge's legal philosophy is systematically linked to a purported proxy, ${ }^{25}$ whereas the nature of law is notoriously controversial. By contrast, answering a question as to the role of some source in one's reasoning on legal questions permits a judge's legal philosophy to have full expression.

We turn now to the particulars of the survey. Work on design of the questionnaire began in October 2005. The decision to proceed with a questionnaire involving structured and unstructured elements was taken with a view to maximizing the depth and comparability of the elicited data. Providing the opportunity for judges to express their views on the nature of the questions posed also promised a greater response rate. Work on drafting the questionnaire proceeded through winter and included exploratory meetings with two British Law Lords. Including 'follow-ons', the final survey contained a total of 25 questions. They appeared in a combination of multi-check, exclusive check, open-ended and simple ranking formats. In the first week of December 2005, letters were sent to the then membership of the British Law Lords, the Caribbean Court of Justice, the High Court of Australia, the Constitutional Court of South Africa, and the Supreme Courts of Ireland, India, Israel, Canada, New Zealand and the United States requesting their participation in a survey on the role of foreign law in domestic rights adjudication. Accompanying each was a personalized cover letter from the chairman of the Oxford Faculty of Law, urging participation in the survey and endorsing our guarantee of confidentiality as regards the identity of participants and their courts.

Given the international dispersion of our intended subjects, interviews were not a feasible option. A system of electronic submission was chosen as the primary data collection method, with the possibility of returning printed out

\footnotetext{
${ }^{25}$ How can we tell that distinctively legal considerations have not factored in the judge's finalizing of his recorded preference (judicial vote or ante-appointment association) or that a political sponsor's policy preferences are not a co-incidental beneficiary of a nominee's legal philosophy? See eg, J Segal and A Cover, 'Ideological Values and the Votes of US Supreme Court Justices' (1989) 83 Am Pol Sci Rev 557 (deriving ideology from the coding of newspaper editorials about each judicial nominee); D Law \& J Fischman, 'What Is Judicial Ideology and How Should We Measure It?' (2008) 29 Washington U J L \& Pol'y 1, 26, 'If judges decide cases simply by applying legal principles in a neutral way, there is no reason why party of appoint[er] should correlate with judicial outcomes.' (emphasis added); M Giles et al, 'Measuring the Preferences of Federal Judges: Alternatives to Party of the Appointing President' (2002) 61 Political Research Quarterly 1 (based on coding the ideology of a nominee's political sponsors); and M Bailey and F Maltzman, 'Does Legal Doctrine Matter? Unpacking Law and Policy Preferences on the US Supreme Court' (2008) 102 Am Pol Sci Rev 369 (taking it as settled that a readiness to overrule a precedent or strike down a statute derives from non-legal reasoning). cf C Shapiro, 'The Context of Ideology: Law, Politics, and Empirical Legal Scholarship' (2010) 75 Missouri L Rev 79, 128, '[R]ather than trying to identify a decision's liberalness or conservativeness, empirical scholars might instead focus on the relative importance or salience of ideology - to the Justices themselves - in different cases.' Disinterest in judicial introspection renders empirical scholarship vulnerable to Dworkinian critiques; see eg. H Gillman, 'What's Law Got to Do with It? Judicial Behavioralists Test the "Legal Model" of Judicial Decision Making' (2001) 26 Law \& Social Inquiry 465 (reviewing H Spaeth and J Segal, Majority Rule or Minority Will: Adherence to Precedent on the US Supreme Court (CUP, Cambridge, 1999)).
} 
hard copies of the questionnaire as an alternative. Oxford's Balliol College agreed to host the survey on its website. The initial letter provided each judge with a unique URL which displayed their personal online copy of the questionnaire. Participating judges saved their inputted responses onto the Balliol server. The responses were then harvested from the server into a personal database. Of 43 survey completions, most were made electronically, with the remainder via hard copy returns. The responses received from each hard copy return were entered manually into its online counterpart. Thirty-one survey completions were filed in response to the first mail-shot-from early December to late January 2006. A first reminder mail-shot was then conducted, netting six further completions. A second reminder (enclosing a survey hardcopy) was sent in mid-March with the final six responses filed in late March/April 2006.

The response rates for the jurisdictions varied considerably; they were as follows: 11 per cent USA, 17 per cent Israel, 18 per cent India, 20 per cent South Africa, 43 per cent Australia, 60 per cent Ireland, 64 per cent UK, 71 per cent Caribbean, 78 per cent Canada, 100 per cent New Zealand. The surveyed British judges comprised the then Lords of Appeal in Ordinary (the 12 fulltime members of the Judicial Committees of the House of Lords and Privy Council) with the exception of Lord Saville of Newdigate. ${ }^{26}$ An initial source of participant selection bias should be noted. In December 2005, the first named author contacted six acquaintances who, as former clerks, had direct access to judges within four of the surveyed jurisdictions, requesting them to bring the initial letter to the attention of their former employer. The response rate from such judges was 50 per cent. Four further acquaintances with indirect access (through current clerks) to judges from two of the former jurisdictions and two additional jurisdictions were requested to do likewise. As the identities of the latter judges were not known to us, we could not calculate their precise response rate. Judging from the number of responses we can account for, however, it seems that three of them responded (43 per cent), providing an overall rate of response from clerk-contacted judges of 46 per cent.

A critical issue is apparent; of whom can the study purport to be representative? The role of a member of the South African Constitutional Court appears to have much in common with that of his Irish and Australian counterparts. The coincidence of a culture of judicial independence, of conflicts with electorally legitimated actors, of a broadly common law tradition, and of the privilege of finality, seems to generate a distinctive professional

\footnotetext{
${ }^{26}$ By the time of the survey, Lord Saville, appointed a Law Lord in 1997, had spent almost seven years away from ordinary judicial business in his role as Chairman of Northern Ireland's second Bloody Sunday Inquiry. He reported earlier this year. The functions of the Judicial Committees of the House of Lords and Privy Council were transferred to the United Kingdom Supreme Court under the Constitutional Reform Act 2005. The new Court started work in October 2009.
} 
role. So is there a genuine category of 'independent apex judges of common law democracies'? One way of thinking about the question is to ask whether, as between the 10 jurisdictions, the professional commonalities amongst our subject judges are greater than the differences. Ultimately, readers must decide for themselves the 'recognizability' of the proposed professional role.

Albeit with a few clear exceptions, ${ }^{27}$ the apex judges of all democratic jurisdictions operating within a broadly common law tradition under conditions of judicial independence were surveyed (103 judges in total). Accordingly, assuming the reality of the suggested professional role, our survey is a reasonable snapshot of the views of the total population who occupy it. Inferences about the attitudes of this population toward the use of foreign law test the hypotheses advanced by the globalist school and suggest new ones. We have deposited our database and questionnaire in the online archive of the Inter-university Consortium for Political and Social Research. Readers are encouraged to download and peruse the data. ${ }^{28}$

The sample's overall response rate was 42 per cent. We speculate that the institutional imprimatur of the then Chair of the Oxford Law Faculty, Ewan McKendrick, contributed significantly to the readiness of judges to respond; this at least was our intention. It is more difficult to account for the wide variations in response frequency. But certain factors are likely to have contributed. First, the nationality of the first named author likely affected the response rate of the Irish Court, whereas Oxford's institutional ties with the senior British judiciary presumably played a role in the response of the House of Lords. Second, the low rate of response from the US Supreme Court may be due to a wariness borne of the Court's unusual prominence within that state's domestic political discourse. Third, we must consider the possible impact of the representations of the 10 former judicial clerks and associates. As it happens, there was no observable correlation

\footnotetext{
${ }^{27}$ Namely, Ghana, Malta and Papua New Guinea. The judges of the Judiciary Committee of the House of Lords (now established as the 'Supreme Court' under the Constitutional Reform Act 2005) conduct the business of the Judicial Committee of the Privy Council, which is responsible for hearing appeals from the courts of a number of Commonwealth countries, to wit, Antigua and Barbuda, Grenada, Bahamas, Jamaica, St. Christopher and Nevis, Belize, Saint Lucia, Cook Islands and Niue, Saint Vincent and the Grenadines, Trinidad and Tobago, Dominica, Kiribati, Mauritius and Tuvalu. No appeal may be made from Scotland's highest court to the Judicial Committee of the House of Lords in a criminal matter. However, under the UK's Scotland [Devolution] Act 1998, the compliance with ECHR rights - as defined in the UK's Human Rights Act 1998 - of all Scottish legislation and criminal procedure is ultimately appealable to the Privy Council. In addition to its responsibility for interpreting the Treaties of the Caribbean Communities, the Caribbean Court of Justice (inaugurated April 2005) is the general final appellate court for Barbados and Guyana; it is intended to eventually assume that responsibility for a number of the Caribbean nations currently subject to the jurisdiction of the Privy Council.

${ }^{28}$ Available via a persistent URL at $<$ http://dx.doi.org/10.3886/ICPSR29121 > . The questionnaire's unstructured element produced a wealth of responses from participants, ranging from substantive elaborations, challenges to the questions posed, commentary on the survey as a whole, and the occasional wry comment. Systematic mining of this data has not been attempted; others are encouraged to do so.
} 
between the number of contacts per court and the rate of response from each court. ${ }^{29}$ Fourth, it is possible that differences in the average workload of the courts affected their respective response rates. We have not undertaken the work of confirming the presence of significant differences between judges in this regard. Beyond the possible effect of these four factors, we are unable to offer any further reasons for the variation in response frequency. Given the wide variation in court-by-court response rates it might be thought that significantly different attitudes towards comparative law among their memberships may bias the data. But the general point to be made at this juncture is that the effect of none of the cited factors - though potentially affecting sample yield - appears likely to produce non-random effects on responses to the questions posed. ${ }^{30}$ Nevertheless, one might worry that there may be a selfselection bias at work due to a judge's personal attitudes toward comparison. In principle, such an effect might cancel itself out, with those anxious to present favourable and unfavourable points of view experiencing an equal marginal inclination to respond. As it was voiced to the authors, however, the concern is that the effect would predominately work to attract responses from those favourable to comparison. It is difficult to test for this given the paucity of judges who are on record as sceptics about the use of foreign law. But what little indication there is does not support the existence of such a self-selection effect. Thus, from one court containing a majority of judges previously on record as optimists about the use of foreign law, the only survey participant previously on record was a sceptic.

Although for a judicial survey our response rate is high, our sample size is small. This has two implications for drawing causal inferences from the data. First, there are likely to be important relationships between variables that

\footnotetext{
29 Though, as noted, the rate of response from contacted judges was marginally higher than that overall.

${ }^{30}$ See McCrudden (n 1) (2000) 517, 'it is likely that there is as great a variation within national courts, as between national courts on the issue [of the use of foreign judgments]; different judges appear to adopt significantly different citation practices.' (citing a citation study of the Israeli Supreme Court 1948-1994, Y Schar, R Haris and M Gross, 'The Character of References in the Supreme Court-A Quantitative Analysis' 27 Mishpatim 1. See similarly Shannon Ishiyama Smithey's comparative study of the attitudes of South African and Canadian judges to the citation of foreign cases in rights decisions; 'A Tool, Not a Master: The Use of Foreign Case Law in Canada and South Africa' (2001) 34 Comparative Political Studies 1188 (concluding at 1207 that '[i]t would appear that the qualities they share, including their common law heritage and the adoption of constitutional provisions protecting civil liberties, were more important than their differences.'); and Bijon Roy's 2004 study of the Canadian Supreme Court, 'An Empirical Survey of Foreign Jurisprudence and International Instruments in Charter Litigation' 62 U Toronto Fac L Rev 99, 125 (reporting wide variations in its members' comparative referencing). Note also empirical work on the US Supreme Court challenging the common conjecture that the youth of a constitution coincides with greater judicial openness to foreign law; S Calabresi and SD Zimdahl, 'The Supreme Court and Foreign Sources of Law: Two Hundred Years of Practice and the Juvenile Death Penalty Decision' (2005) 47 Wm \& Mary L Rev 743, 755, '[T] he [US Supreme] Court has cited foreign law with much more frequency in far more important constitutional cases as the Court has grown older and has increased significantly its use of such sources in striking down legislation only since Trop v Dulles in 1958.'
} 
do not show up as statistically significant. Second, those relationships which $d o$ register as statistically significant are likely to be important. ${ }^{31}$ In reviewing the data, bear these points in mind.

Our analysis will proceed thematically; the first two sections set out findings relevant to hypotheses about the sociological impact of foreign judges and domestic audiences. The subsequent sections present findings relevant to a variety of claims about the basis on which judges use foreign law. In the final section we signal a difficulty raised by the data for Dworkinian claims about the nature of appellate judicial reasoning.

\section{FINDINGS}

At the head of the questionnaire ran the following notice:

Please read the word 'rights' to mean human and/or civil rights... Bear in mind that your participation in this study is entirely confidential-no references whatsoever will be made either to specific participants or their courts.

Of the total population of apex judges of common law, democratic jurisdictions, the membership of the 10 aforementioned courts - 103 judges - were surveyed. In total, 43 judges responded, giving us a response rate of 41.7 per cent. This represents a margin of error of 11.4 per cent. A 95 per cent confidence interval was selected; any significant results found should be repeated on 95 per cent of occasions. As data were of a nominal nature, Pearson Chi squared analyses were employed in order to determine relationships between the variables.

\section{A. Foreign Judges as Reference Group}

Our survey establishes fairly clearly that at least some foreign judges form a professional reference group for nearly all judges. ${ }^{32} \mathrm{We}$ found that 93 per cent of judges felt 'a sense of high professional esteem for Supreme Court judges from other jurisdictions' (Question 3). ${ }^{33}$ A follow up question asked: Is this sense of professional esteem greater than that which you feel towards subordinate judges in your own jurisdiction? ${ }^{34}$ Fourteen respondents did not answer this question of relative esteem - many of whom rejected the possibility of generalization. Of those that answered, 16 perceived their sense of professional esteem for foreign judges and their subordinate domestic judges to

31 See R Lempert, 'The Significance of Statistical Significance' (2009) 34 Law \& Social Inquiry 225.

32 'Judge' denotes a member of an apex court of a common law democracy.

33 Of the 42 answering judges, 63 per cent responded 'yes', with a further 30 per cent indicating that they felt such a sense of esteem 'to some extent'. Those adding distinctive comments to their answers split between saying that their answer depended on the jurisdiction (4) or judge (3) in question. 
be equal. Twelve indicated that they held a greater sense of professional esteem for their foreign counterparts than their domestic subordinates, with only one judge indicating the opposite. One of the former observed that ' $[\mathrm{h}]$ aving served in lower and intermediate courts, and on a final court, one discovers a special empathy with judges who work at the end of the track.'

It is also fairly clear on the data that, for a considerable proportion of judges, at least some foreign judges form a reference group in relation to constitutional rights. The response to Question 1 supplies some context. It asked:

In those parts of your judgments which relate to rights, to what extent do you refer to the law in other national jurisdictions?

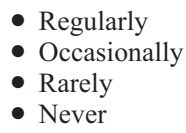

All 43 judges responded to the question, with none answering 'never'. Evidently, the frequencies people attribute to the terms 'rarely' and 'occasionally' are likely to have a substantial overlap. We suggest, however, that there is little overlap between the frequencies people are likely to attribute to the terms 'occasionally' and 'regularly'. Accordingly, our analysis groups two of Question 1's answer options, 'rarely' and 'occasionally' together; leaving the remaining frequency option, 'regularly' to stand alone. ${ }^{35}$ Of the 43 judges, 20 felt that they used foreign law occasionally or rarely while 23 felt they used it regularly. For ease of reference we will label the latter kind of judge a 'frequent' user, the former 'infrequent'.

Our second frequency question was more precise. Question 6:

Do you use comparative material in justifying your legal conclusions on rights?

- Regularly

- Occasionally

- Rarely

- Never

All judges answered the question; we analysed their answers in the same manner as Question 1. Fifty-six per cent considered themselves infrequent users of comparative material when it came to justifying their legal conclusions on rights. Forty-two per cent considered themselves frequent users. Only one judge answered that he never used comparative material in justifying his legal conclusions on rights (though he did note his use of such material in other ways, 'rarely'). We found that the frequency with which judges used

\footnotetext{
${ }^{35}$ We are not aware of any documentary citation study that has comprehensively investigated an apex court's reported citations of foreign law. Our survey's citation frequency questions ( 1 and 6) would certainly have been better served by documentary investigation. Should a future team carry out such work, it would permit them to draw more precise correlations with the other questions posed.
} 
comparative material in justifying their legal conclusions on rights was significantly related to the frequency with which they cited foreign law $(\chi 2=21.11, \mathrm{df}=2, \mathrm{p}>.05){ }^{36}$

The response to Questions 1 and 6 is consistent with the claim that foreign judges form a judicial reference group on constitutional rights. The claim is positively supported by number of judges indicating they had had personal contacts with judges of other jurisdictions that had contributed to their analysis of domestic rights (49 per cent); (Question 14). Such judges tended to be frequent citers of foreign law. The claim is also supported by the contrast which emerged with respect to Question 3B: 44 per cent of frequent citers held foreign judges in higher professional esteem than subordinates, compared with only 10 per cent of infrequent citers. Had the two judges who indicated no particular sense of professional esteem for foreign judges - both infrequent citers - taken the opportunity to register their relative esteem, the contrast would presumably have been more pronounced. The claim is likewise supported by the finding of a statistically significant relationship between the prioritizing of attendance at a speech by a foreign judge on rights (a priority attributable to over 50 per cent of judges generally) and the justificatory citation of foreign law (Questions 6 and 16).

Three explanations of how foreign judges could come to form a reference group in relation to rights have been suggested: that judges look abroad to reinforce their own professional status, to strategically influence foreign groups/satisfy the urge to belong to a perceived community of nations, and to reach better legal decisions. Ostensibly, the operation of a reference group in any one of these ways on a given judge is mutually exclusive - making the prevalence of one all the more interesting. Before addressing their prevalence, we consider the more general question of judicial audience impact.

\section{B. Audience Impact}

Question 12 asked:

Who is your judgments' typical audience comprised of?
a) The parties to the dispute
b) Respected judges
c) Agencies/Organs of the State
d) Subsequent generations
e) The international community, broadly conceived
f) God
g) Other-please specify

All judges answered this question, and none indicated that they considered God to comprise part of their judgments' audience. Only three judges

\footnotetext{
36 Just 26 per cent of frequent citers of foreign law indicated they did not use it frequently in justifying their conclusions on rights.
} 
(seven per cent) indicated that their audience was comprised solely of the parties to a dispute, whereas only two excluded the parties. Sixty-five per cent considered agencies or organs of the State part of their audience, while almost a third of participants held subsequent generations in this light. Almost a fifth considered the international community part of their judgments' audience. Emerging through the 'other' column, also with 19 per cent, was the category of lawyers potentially affected by one's judgment, be it subordinate judges or practitioners. ${ }^{37}$ Another set of audience members emerging, with 16 per cent volunteering it, was the general public or 'man on the street'. ${ }^{38}$ The final 'written in' audience category was academia, with 9 per cent describing it as part of their audience. ${ }^{39}$

Twenty-one judges (49 per cent) indicated that respected judges formed part of their judgment audience. All but one of these respondents had answered positively ('yes' or 'to some extent') when asked if they held foreign judges in high professional esteem (Question 3). Accordingly, it seems that foreign judges constitute part of the perceived judgment audience of almost half of our respondents.

By and large, it is as one might expect; the perceived judgment audience of an apex judge will include the parties; usually the organs of State; sometimes posterity; and rarely, academia. The relatively low ranking attributed to the general public is consistent with much American research. ${ }^{40}$ Perhaps more surprising is the extent to which respected judges feature, and, by extension, foreign judges. Considering the number of academics devoting their careers to dissecting and criticizing the decision-making of apex judges, it suggests the self-sufficiency of the judiciary as its own professional reference group. Perhaps it should indeed be thought of as a 'guild'. ${ }^{41}$

Our data offer modest help with the general question of whether perceived judicial audiences affect judicial decision-making. In the face of what would seem to have been a countervailing bias, a third of judges said that they were responsive to their audience's attitude towards the use of comparative material (Question 12A). If there is indeed an audience effect on decision-making, it must still be decided whether it is for esteem in itself that judges are working. ${ }^{42}$ In this regard, consider that most judges who indicated their

\footnotetext{
${ }^{37}$ Respondent identity codes: 132, 736, 322, 133, 909, 690, 455, 924.

38 ibid: $369,132,909,783,764,342,747$.

39 ibid: $369,372,268,455$.

$40 \mathrm{~N}$ Persily, 'Introduction' in Persily, J Citrin, P Egan (eds), Public Opinion and Constitutional Controversy (OUP, Oxford, 2008) 3, 8 (summarizing empirical work as generally indicating that 'the effect of public opinion on Court decisions exists as a complex process in which public moods get incorporated through the appointment of new justices or through responses by other branches of government.')

41 'We're a guild, just like physicians or military people are guilds'. US Justice Anthony Kennedy speaking to Jeffrey Toobin, 'Swing Shift' The New Yorker (September 12, 2005).

${ }^{42}$ Lawrence Baum makes a prima facie case that, at times, it may well be; Judges and their Audiences (Princeton University Press, Princeton, 2006).
} 
responsiveness to their audience's attitude toward comparative material had noted 'respected judges' as part of their perceived audience (just under a quarter of total respondents). ${ }^{43}$ Assuming there is no particular strategic value to the apex judge in responding to the perceived priorities of 'respected judges', and that responsiveness towards a 'respected' source would not be merely presentational, these data tend to suggest the occurrence of nonstrategic forms of audience responsiveness in judicial decision-making. ${ }^{44}$

We have noted reasons for confidence that, for many judges, foreign judges constitute a reference group in relation to constitutional rights. We have also noted three possible bases for the development of such a group - to reinforce professional status, to strategically influence foreign groups/satisfy the urge to belong to a perceived community of nations, and to enhance the quality of one's legal conclusions on rights. We now assess the likely prevalence of each basis, along with that of the null hypothesis - that foreign judges and legal systems are used merely to indicate the merit of outcomes in whose determination they have not in fact had an input.

\section{Basis I-Inter-state Acceptance/Influence}

The data offer mixed support to the hypothesis that judges compare in order to help satisfy the urge to belong, or sense of belonging, to a perceived community of nations. ${ }^{45}$ Eight judges indicated that the 'international community' was part of their judgment audience. Of these judges, half perceived themselves as audience responsive and three quarters were frequent foreign law citers. However, the dismissal of both foreign law as a source of information on the moral attitudes/viewpoints prevailing abroad ${ }^{46}$ and of 'the gains to your

\footnotetext{
43 This is consistent with evidence of the impact of peer respect on US Circuit Court decisionmaking; D Klein, Making Law in the United States Courts of Appeals (CUP, Cambridge, 2002) 95 (24 interviewees from the total Circuit bench).

${ }^{44}$ Compare L Epstein, J Knight and A Martin, 'Review Essay: The Supreme Court as Strategic National Policy-Maker' (2001) 50 Emory L J 583 (emphasizing the legislature as audience).

${ }^{45}$ See eg, Slaughter (n 1) (1994) 133-134 '[T] he creation or generation of a legal community through transjudicial communication could itself help define and strengthen common political and economic values in the states concerned.'; F Schauer, 'The Politics and Incentives of Legal Transplantation' CID Working Paper No. 44 (2000) $18<$ http://www.cid.harvard.edu/cidwp/pdf/ 044.pdf > 'Hypothesis 3: The political reputation of the donor country... is a causal factor in determining the degree of reception in the recipient country of the donor country's legal ideas, norms, and institutions, even holding constant the host country's evaluation of the intrinsic legal worth of those ideas, norms, and institutions.'

${ }^{46}$ Question 2: If you use law from other national jurisdictions in relation to rights is it primarily as a source of

- Different methods of legal reasoning OR

- Information on moral attitudes OR

- Information on the consequences of a particular decision

- Other

A solitary judge specified 'moral attitudes.' Similarly, only 10 judges included 'moral viewpoints prevailing elsewhere' as something about which international judicial conference can be a helpful source of information (Question 5A).
} 
state's international standing from a visible judicial engagement with foreign ideas and attitudes' ${ }^{47}$ suggest that comparison for the sake of inter-State acceptance is not widespread. Equally, for these reasons, and in light of the relatively little emphasis placed on 'assisting the work of establishing enlightened approaches to rights in emerging democracies' ${ }^{48}$ the data suggest a similar verdict for the alternative hypothesis that judges compare so as to strategically influence foreign groups. ${ }^{49}$

\section{Basis II-Transnational Judical Acceptance}

The two remaining explanations of how foreign judges could come to form a reference group in relation to rights appear somewhat better supported. Take the hypothesis that judges are seeking to be rewarded with professional approval or acceptance. ${ }^{50}$ Question 16 asked:

If, at a conference, you had to decide between attending five different speeches on rights without knowing what topics the speeches would address, which would you choose? Please rate in order of priority. $5=$ highest

a) The speech by the subordinate domestic judge

b) The speech by a member of your own court

c) The speech by a supreme court judge from abroad

d) The speech by a domestic academic

e) The speech by an academic from abroad

There were eight non-responses, many of whom considered the hypothetical unanswerable in the absence of information on speaker identity. (Though the comment of one such judge took a different tack, 'I would avoid all of the speeches like the plague. There is no end to lectures, conferences etc on the topic. They tend to be extremely dull.') Of those who answered, 23 (68 per cent) gave their highest preference to attendance at the speech by the foreign judge (53 per cent overall). Consistent with the current hypothesis, there was a statistically significant correlation between prioritization of attendance at a foreign judge's speech and justificatory citation of foreign law

47 See Question 9, discussed below.
48 ibid.

49 See (Justice) Michael Kirby of Australia, 'It follows that engaging, in the analysis of analogous points, with the opinions of judges and other writers in many countries, helps ensure national courts against intellectual isolation and, consequentially, a diminished influence of their own in the world of ideas.' Kirby (n 6).

50 See Slaughter (n 1) (2004) 101 (Observing of inter-supreme court citation that 'the psychological impact is considerable, leading judges to feel part of a larger judicial community...'); Bahdi (2002) 595, 'Increasingly, judges want to belong not simply to a domestic community of judges but also to an international juridical community. Greater interaction between judges in both real and virtual space both reflects and promotes this judicial desire to belong to a transnational community of their peers.'; Young (2005) 157, 'Even among those skeptical of the merits of 'indirect normative influence' its influence is supposed: Interactions between legal elites on a global scale make it increasingly likely that the views of lawyers and jurists abroad will form part of the reference set for our own Justices as they formulate their own moral views...' 
$(\chi 2=19.25, \mathrm{df}=6, \mathrm{p}<.05)$. The hypothesis is also consistent with the large proportion of judges for whom foreign judges form part of their judgment audience (47 per cent), and the fact that half of those judges noted their responsiveness to their audience's attitude towards the use of comparative material. ${ }^{51}$ The hypothesis is positively supported by the statistically significant tendency of those indicating a greater sense of professional esteem for foreign judges over domestic subordinates to think international human rights law the tool most useful for resolving rights questions - it may be seen by some as an opportunity to engage in the interpretation of common legal instruments. ${ }^{52}$ As against it, there is the lack of an appreciable correlation between high professional esteem for foreign judges and frequency of comparative citation (Question 3). Equally, there is the degree of opportunism apparent in attitudes towards the use of foreign law (Question 9):

Which, if any, of the following considerations might justify the citation of comparative material in the interpretation of domestic rights? (Please rate in order of importance) $8=$ highest.

a) The gains to your state's international standing from a visible judicial engagement with foreign ideas and attitudes.

b) It provides an additional source of impartial guidance (such as precedent), thus facilitating objectivity in judicial interpretation.

c) It provides an additional factual source, thus enabling the court to make more accurate predictions as to the effects of challenged laws and rights.

d) It provides an additional source of legal authority, thus increasing the chances that a legal authority can be found to match what you already believe to be the best result from a policy perspective.

e) It assists the work of establishing enlightened approaches to rights in emerging democracies.

f) The importance of upholding comity between judges internationally.

g) It demonstrates that the judicial review of legislation for compatibility with rights also happens in other respectable democracies.

h) Other-please specify.

Twelve of the question's 40 respondents (30 per cent) ranked $\mathrm{B}$ the most important consideration justifying the citation of comparative material; 8 respondents (20 per cent) ranked D the most important; 5 (12.5 per cent) ranked E most important; while the rest received negligible attention. ${ }^{53}$ As an admission of false advertising, there would seem to be a strong bias against

${ }^{51}$ See 'Audience Impact' above.

${ }^{52}$ Questions 4 and 3B $\left(\chi^{2}=20.45, \mathrm{df}=9, \mathrm{p}<.05\right)$. Question 4 asked: Which tool do you consider most useful for identifying the protection to be given to rights asserted in your court?

- The domestic constitution

- International human rights law

- Moral thinking on human nature

- Religion

53 This casts some doubt on the hypothesis that, since 2000, 'the driving force behind reliance on foreign law' has been the felt need 'to forge a united judicial front. . . to protect or even reclaim the domestic political space that is increasingly restricted by the economic forces of globalization and the delegation of authority to international institutions...'. Benvenisti (n 4) 242-244. 
judges revealing - even in a confidential survey - the view that the most important reason for resort to comparative material is that it increases the chances that a legal authority can be found to match what one already believes to be the best result from a policy perspective.

\section{E. Basis III-Decision Enhancement}

We come now to the epistemic basis for the development of foreign judicial reference groups; that judges look to foreign law because they feel it increases the chances of their reaching the correct legal conclusion. This is the picture suggested by the emphasis on judges' increased sensitivity to foreign law as persuasive authority. ${ }^{54}$ The epistemic hypothesis is consistent with the substantial proportion of judges who acknowledge making indirect use of their legal knowledge of other countries, ${ }^{55}$ at least to the extent that such usage is deliberate. If such usage is deliberate, however, it appears in tension with the principle that the legal reasons for judgment are to be cited.

The epistemic hypothesis is also consistent with the significant negative correlations between, on the one hand, the justificatory usage of foreign law and, on the other, the views that the constitutional protection of rights is best secured by reference to national sources alone (Question 15; $(\mathrm{sr}=3.0$ $\chi 2=18.47, \mathrm{df}=8, \mathrm{p}<.05))$ and that the citation of comparative material is undemocratic (Question 11; $(\chi 2=11.88, \mathrm{df}=2, \mathrm{p}<.05)$ ). ${ }^{56}$ Equally, it is

${ }^{54}$ See (n 2) above. Similarly, A Hamann and H Ruiz Fabri, 'Transnational Networks and Constitutionalism' (2008) 6 Int'l J Con L 481, 498, 'It seems that this phenomenon of "constitutional cross-fertilization" where foreign approaches are... acknowledged and discussed, progressively reveals the emergence of a global constitutional jurisprudence.'; R Dixon, 'A Democratic Theory of Constitution Comparison' (2008) 56 Am J Comp L 947, 992, 'a dynamic-reflective theory [on the benefits of comparison in helping shed light on the evolution of constitutional understandings] ... has the advantage of speaking directly to the recent practice by members of the [US Supreme] Court in the particular jurisprudential contexts in which it has arisen.'; J Waldron, 'Foreign Law and the Modern Ius Gentium' (2005) 119 Harv L Rev 129, 146, 'for those who see legal decision as a matter of reasoning one's way through problems, my account [of it as a matter of patient analysis, the untangling of issues, the ascertaining of just resolutions, and the learning and cooperation that is characteristic of a scientific approach] may help to explain why courts turn naturally to foreign law.'; PG Carozza, ' "My Friend is a Stranger": The Death Penalty and the Global Ius Commune of Human Rights' (2003) 81 Tex L Rev 1031, 1081-1082 (that judicial comparison is 'first and foremost, the working out of the practical implications, in differing concrete contexts, of human dignity for the rights to life and physical integrity'.).

55 Per Question 8; 'Do you make indirect use of your legal knowledge of other countries in your judgments on rights?' Of the 40 judges expressing an opinion, twenty three answered affirmatively. Indirect usage is predicted by the globalist school; eg, Slaughter (n 1) (1994) 118; J Resnik, "Law as Affiliation: "Foreign" law, Democratic Federalism, and the Sovereigntism of the Nation-state' (2008) 6 Int' 1 J Con L 33, 46 (judges are learning from each other through 'silent dialogues'.). Note that respondents who frequently refer to foreign law in their judgments are more likely to consider themselves indirect users of such knowledge.

${ }^{56}$ We found a significant correlation between 'nationalist' responses to Question 15 and negative attitudes towards 'living constitutionalism' (Question 18); $(\mathrm{sr}=2.7, \chi 2=26.4 \mathrm{df}=12$, $\mathrm{p}<05$ ). See (US Justice) A Scalia, 'Foreign Legal Authority in the Federal Courts' (2004) 98 Am 
consistent with the fact that most judges say their approach to comparison is affected by a concern that they may not fully appreciate the legal and factual context surrounding material from other jurisdictions (Question 13). ${ }^{57}$ On this point, consider Question 10:

Which traits must other jurisdictions possess to justify their citation in a judgment about domestic rights? Please mark as many as appropriate.

a) None in particular

b) They must be democratic

c) They must be a 'common law' jurisdiction

d) They must speak the same language

e) They must have close historical links (such as a colonial association etc.)

f) Other-please specify

A large majority of judges, 81 per cent, indicated that a democratic form of government was a prerequisite for the citation of the law of another jurisdiction in a judgment about domestic rights. Conversely, 17 per cent of judges indicated they set no jurisdictional prerequisites. Only a single judge indicated a set of traits that did not include democracy, namely, that it be a common law jurisdiction. Other than democracy, the most cited prerequisite was that it be a common law jurisdiction ( 26 per cent), followed by commonality of language (14 per cent). There were seven comments to the effect that, were a jurisdiction to possess the 'same language' and 'common law' traits, it would be more readily comparable, but that, democracy aside, such traits were not a sine qua non.

That most judges indicate adherence to general criteria in assessing the comparability of a jurisdiction is consistent with the epistemic hypothesis. ${ }^{58}$ Nevertheless, the lukewarm support shown for foreign law as an aid to legal objectivity (only 30 per cent of responding judges rating it the most important justification for citing comparative material), as an aid to making accurate predictions as to the effects of challenged laws and rights (also Question 9), and for discovering foreign moral attitudes and viewpoints (Questions 2 and, less so, 5A) weigh against the idea that judges compare according to the rational ideal.

Society Int'1 L Proc 305, 308, 'One who believes it falls to the courts to update the list of rights guaranteed by the Constitution tends to be one who believes in a Platonic right and wrong in these matters... [and will thus] consider the views of all intelligent segments of mankind.'

57 See eg, H Collins, 'Methods and Aims of Comparative Contract Law' (1991) 11 OJLS 397 (illustrating the potential difficulties for legal comparison caused by the potential interdependence of different elements of a foreign legal system).

58 Compare DA Amann, "Raise the Flag and Let it Talk": On the Use of External Norms in Constitutional Decision Making' (2004) 2 Int'1 J Const L 597, 604, 'The dearth of methodological guideposts opens courts to the criticism that foreign practice does not really aid deliberation but merely cloaks otherwise unsupported policy decisions in a guise of constitutional legitimacy.' 


\section{F. Foreign Law as Faux Reference}

Finally there is the possibility that foreign judges and legal systems are a faux reference group; that they are used to advertise the merit of decisions in whose determination they had in fact no input. This has been a much-debated matter. The battle lines are not clearly drawn between those pro- and antijudicial comparison, however - at times critics of comparison have assumed its decisional impact, ${ }^{59}$ while its supporters have described attractions that suggest the play of opportunism. ${ }^{60}$ Evidently, the existence of foreign judges and legal systems as a faux reference group is at odds with the epistemic model of judicial comparison. Consider Eric Posner and Cass Sunstein's suggestion that:

[T] he pervasiveness of this practice [the frequent consultation of foreign law by courts] is best understood by reference to the Condorcet Jury Theorem: if many courts have decided on a particular course of action, and if each of them is likely to make choices that are better than random, there is excellent reason to believe that this course of action is right. ${ }^{61}$

On the other hand, accusations that comparing judges engage in citational 'cherry-picking' have been prominent in both the academic literature and official judicial opinion. ${ }^{62}$ Comparative law is said to lend itself to such opportunism in a way that domestic precedent does not; that 'any judge wanting a supporting citation has only to troll deeply enough in the world's corpora juris to find it. ${ }^{63}$ In response, globalist scholars note the presence of 'increasing numbers of judges in particular jurisdictions who appear to consider it important to distinguish judgments of foreign courts if they go against the conclusion that the judge intends to

\footnotetext{
59 Eg, C Manfredi, 'The Use of United States Decisions by the Supreme Court of Canada under the Charter of Rights and Freedoms' (1990) 23 Canadian J Pol Sci 499, 517-518, 'The qualitative impact of these [US] citations has also been significant... judicial supremacy of the type reflected in the American jurisprudence used by the post-Charter Court potentially denies Canadians their most basic freedom and right of self-governance.'; K Anderson, 'Squaring the Circle? Reconciling Sovereignty and Global Governance through Global Government Networks' (2005) 118 Harv L Rev 255, 1310, "[I]f the Justices and the federal courts were to move along that road [introduce the persuasive authority of foreign precedent], then it would seem to me quite appropriate for Congress to [strip]... the federal courts of jurisdiction over certain matters, thereby preserving the balance of democratic governance.'

${ }^{60}$ See Slaughter (n 1) (1994) 135, '[C]ourts bolstered by communication with other national and supranational courts will be bolstered in their efforts to make their own voices heard.'

61 'The Law of Other States' (2006) 59 Stan L Rev 131, 179. Sunstein has since offered a more circumspect analysis; see CR Sunstein, A Constitution of Many Minds (Princeton University Press, Princeton, 2009) 209.

${ }_{62}$ Perhaps the most forceful examples of the latter are those of Justice Scalia, 'To invoke alien law when it agrees with one's own thinking, and ignore it otherwise, is not reasoned decisionmaking, but sophistry.' Roper v Simmons, 543 U.S. 551 (2005) (dissenting). Citing Justice Livingstone's dissent in United States v Smith 18 US (5 Wheat) 153, Calabresi and Zimdahl (n 30) report that 'Justice Scalia's modern lament finds its echo from as long ago as 1820 in the US Reports'; 754.

${ }^{63}$ (US Circuit Judge) Richard Posner, ‘A Political Court' (2004) 119 Harv L Rev 31, 86.
} 
reach. ${ }^{64}$ The greater the practice of distinguishing foreign law, the more its citation has in common with the citation of domestic court decisions. An inclination to distinguish foreign law certainly suggests an interest that goes beyond mere ad hoc cherry-picking. But even if the practice of distinguishing foreign law were fully developed, that would not resolve the matter-there remains an open debate on the extent to which domestic precedents in fact constrain apex judges. $^{65}$

The notion that foreign law is cited because indications of correspondence with other jurisdictions are useful for persuading domestic observers of the legal merits of a decision is supported by Question 9. Despite what must have been a strong countervailing bias, 20 per cent rated 'increasing the chances that a legal authority can be found to match what you already believe to be the best result from a policy perspective' the most important reason for resorting to comparative material. Two-thirds ranked it an important consideration justifying the citation of comparative material, ie, 67 per cent of judges gave it at least their third highest ranking, where those ranking third provided five or more rankings. Looking abroad for the purpose of finding legal authorities to match what one already believes to be the best result from a policy perspective is conceptually distinct from offering comparative citations as 'sales puff' for what one anyway believes to be the only legally correct decision. It is also distinct from reaching a policy decision by way of foreign examples; the decision is already made.

The faux reference model is consistent with the published empirical work on the question, limited though that is. Thus, Alan Paterson's landmark 1982 study of the British House of Lords found that 'the Law Lords have experienced little or no difficulty in rejecting or ignoring the consensus of these other countries [those typically cited] when they prefer to retain their own line. ${ }^{66}$ Bijon Roy's recent citation study of the Canadian Supreme Court also offers relevant data. Roy reports that of the 402 Charter of Rights cases decided between 1998 and 2003, 34 contained opinions featuring a total of 87 individual references to foreign law. Forty-two of these references are reported to have been used in support of the referring opinion's conclusion, with 16 used to distinguish the relevance of the foreign approach. 29 references were characterized as 'surveys'. The latter were 'often used' to 'demonstrate an established or emerging pattern' ${ }^{67}$ consistent with the Court's analysis.

A citation bias seems apparent on Roy's figures. Why did judges encounter foreign law that agreed with their ultimate conclusion 75 per cent of the time? It was not because of a strong general inclination to adopt the position of the foreign jurisdictions in question. If that were the case, there would surely have

64 McCrudden (n 1) (2000) 517.

65 See eg, the authors cited at (n 25) and (n 78).

66 A Paterson, The Law Lords (University of Toronto Press, Toronto, 1982) 19.

67 Roy (2004) 129. 
been reference to these jurisdictions in more than 34 of 402 Charter decisions. Presumably, foreign law was but one of a number of factors in the determination of these decisions, one which, only very occasionally, might have made the difference. But, if so, why does foreign law happen to stack up on the side of the judge's ultimate conclusion three times out of four? Moreover, Roy reports no clear instance of a judge acknowledging foreign law as relevant, but outweighed. ${ }^{68}$ Strictly, it seems the judges did not once recognize the position of one of the foreign jurisdictions as being on point but at odds with their ultimate conclusion. ${ }^{69}$

The evidence of current judicial practice does not quite support Padyuma Tripathi's observation that the positions of foreign legal systems:

[P]ossess no compelling force of their own;... any or all of them could be conveniently ignored altogether; and, of course, any of them could be cited in support of a decision where it happens to suit. ${ }^{70}$

But neither does the evidence make it look foolish. It seems that globalists have correctly identified an interesting factor in judicial decision-making; that, for many judges, foreign judges form a reference group in relation to constitutional rights. Conversely, the data suggest that the globalist conception of judges citing foreign law as a source of persuasive authority may apply to only a minority of judicial comparativists. Citational opportunism and the aspiration to membership of an emerging international judicial 'guild' appear to be equally important strands in attitudes towards the use of foreign law.

\section{IMPLICATIONS FOR THE THEORY OF LEGAL REASONING?}

The respectable showing of the opportunistic and sociological models of judicial comparison suggests a more general point about the nature of apex adjudication. Consider Ronald Dworkin's theory of legal objectivity, 'They [critics] think I must be saying not just that there are right answers in some ordinary way, as an unselfconscious lawyer might say that....71 While Dworkin cites his theory' consistency with the views of working lawyers, ${ }^{72}$ he

${ }^{68}$ See ibid 133-334 (the closest example noted is $R v$ Fliss [2002] 1 SCR 535 paras 47-48 in which the Court stated that it 'took a different view' from the foreign position.

${ }^{69}$ Roy's figures are consistent with J Allan et al, 'The Citation of Overseas Authority in Rights Litigation in New Zealand: How Much Bark? How Much Bite?’ (2007) 11 Otago L Rev 1 (finding that, of the 75 major reported cases in which the New Zealand apex court referred to overseas rights-based decisions from 1990 to 2006 ,' 28 of them include a reference to an overseas case that did not support the New Zealand court's eventual conclusion. . . [a]nd that figure overstates things to the extent that in some cases only one of the multiple [concurring] judgments [relying on foreign law] made such a reference'; 8).

70 P Tripathi, 'Foreign Precedents and Constitutional Law' (1957) 57 Colum L Rev 319, 346.

71 'Pragmatism, Right Answers, and True Banality' in M Brint and W Weaver, Pragmatism in Law and Society (Westview Press, 1991) 359, 365 (emphasis added).

72 Dworkin (n 2) 90, 'The old plain-fact picture of Chapter 1 told us not to take the opinions judges write in hard cases at face value; the new picture [of jurisprudence] has the signal merit of 
has questioned the value of the survey as a means of revealing them. ${ }^{73}$ The essence of his concern is captured in the quote above; what is important is what lawyers think, not what they think they are supposed to think. The use of a survey to generate evidence to test a legal theory of whose dominance judges are conscious, will be vulnerable to the criticism that it reveals only what they think they are supposed to think. Accordingly, Dworkin rejects judicial surveys. ${ }^{74}$ But the corollary of Dworkin's criticism is also captured by the quote - if the way in which there are right answers to legal questions manifests itself in how unselfconscious lawyers talk, it is vulnerable to evidence impugning the possibility of certain kinds of unselfconscious talk.

It is submitted that the inadequacy of the romantic story of judicial comparison is an inadequacy of the romantic story of apex adjudication. In the context of a survey on the use of a particular legal source, Question 9 asked what might justify the citation of comparative material in the interpretation of domestic rights. It did not ask judges to give their theory of law, to offer their view on whether some school of jurisprudence has it right. Equally, it did not ask judges whether they think all legal questions have legally determined answers. It simply asked about the value of a particular kind of legal source in a particular field of law. Those judges who answered that the source 'provides an additional source of legal authority, thus increasing the chances that a legal authority can be found to match what you already believe to be the best result from a policy perspective' revealed a theory of the source's value at odds with a belief that there are always legally right answers. Such judges — of whom there was a significant number-could not unselfconsciously think that there are legally right answers in cases in which they would be ready to cite foreign law.

allowing us once again to believe what our judges say.' (emphasis added); See also D Brink, 'Legal Interpretation, Objectivity, and Morality' in B Leiter (ed), Objectivity in Law and Morals (CUP, Cambridge, 2001) 12, 48 (noting, in defence of Dworkin's theory, that 'interpreters typically act as if hard cases have a best [legal] interpretation'). Conversely, 'Dworkin's most powerful descriptive criticisms of conventionalism [legal positivism] focus on the phenomenology of judging in hard cases.' K Kress, 'The Interpretive Turn' (1989) 97 Ethics 834, 859. Indeed, in a noted positivist response to Dworkin's critique, Joseph Raz appears to concede that judges believe that their 'decisions always represent the state of the law at a time just prior to their decision'. Raz, 'Two Views of the Nature of the Theory of Law: A Partial Comparison' in J Coleman (ed) Hart's Postscript (OUP, New York, 2001) 1, 34 n 46.

${ }^{73}$ See the discussion in Paterson (n 66) 2, 194-195 citing Dworkin; and Dworkin (n 2) 10, 'The plain-fact view [that when judges appear to be disagreeing in a theoretical way as to what the law is, they are really disagreeing as to what it should be]... is rejected in the accounts thoughtful working lawyers and judges give of their work. They may endorse the plain-fact picture as a piece of formal jurisprudence when asked in properly grave tones what law is. But in less guarded moments they tell a different and more romantic story.' The concern is echoed by Stephen Guest; Guest, 'Objectivity and Value' in M Freeman and R Harrison (eds), Law and Philosophy (OUP, Oxford, 2007) 76, 90, 'Are the highest appellate courts a... place where the different statements of law are not correctable... It seems unlikely, not least because of the way lawyers, and the courts themselves, unphilosophically speak.' (emphasis added).

${ }^{74}$ The sort of distinction Dworkin associates with the use of surveys is the converse of that associated by authors of prominent 'Realist' explanations of judicial behaviour; see (n 20). 
In concluding that the proportion of opportunistic citers of foreign law is significant, we acknowledged the presence of a bias against revealing such motives, even in an anonymous survey. The reasons for thinking a bias against such answers exists are likewise reasons for doubting that judges thought that they were supposed to think such answers appropriate. The first reason seems to apply equally to the question of whether all legal issues have legally determined answers; that, in justifying their decisions, judges almost always write as if the issue at hand has a legally determined answer. The second reason is that much of the criticism levelled at the citation of foreign law in rights cases is that the practice is, or is liable to become, opportunistic. Judges conscious of the recent debate about comparative law will be aware of this criticism and accordingly unlikely to imagine that they are supposed to think that foreign law is to be cited opportunistically. We also supported the conclusion by noting our data's consistency with Roy's documentary citation study of the Canadian Supreme Court - a form of inquiry that, by its nature, is not vulnerable to introspection bias. ${ }^{75}$

Moreover, the data indicate that some judges use comparative material to earn the professional approval of 'respected' foreign judges. Responsiveness towards a 'respected' audience seems unlikely to be merely presentational. As such, judges using foreign law to earn professional approval seem likely to give it a genuine decisional input. In acting out of a desire for acceptance, such judges do not understand the outcome of rights cases in which they apply foreign law as a matter with respect to which personal social gain is coincidental. Accordingly, if they believed such cases to have legally correct answers, they would be acting in bad faith by deciding them with a view to securing the greatest social reward. It seems best to assume that they do not consider the cases to have legally determined answers.

In light of the apparent footing of the sociological and opportunistic models of judicial comparison, the survey data appear to present a range of cases in which many or most judges do not regard themselves as pursuing the discovery of the legally correct answer. ${ }^{76}$

A question seems prima facie less likely to have a determinate answer if it is one which eludes a significant number of informed observers. It follows that the obvious candidates for legal questions lacking legally determinate answers are those which are judicially controversial. Thus it is noteworthy that citation studies of judicial comparison have found statistically significant correlations between the citation of foreign law and the number of opinions filed in a

\footnotetext{
${ }^{75}$ See text accompanying (n 66-69).

${ }^{76}$ Contrast Dworkin, '[T]here is no positive evidence of any kind that when... judges seem to be disagreeing about the law they are really keeping their fingers crossed. .' Dworkin (n 72) 39 and Brian Leiter, 'According to positivists... theoretical [legal] disagreements are disingenuous, in the sense that the parties... are trying to say, as Dworkin puts it, "what it should be" not "what the law is." ' Leiter, 'Explaining Theoretical Disagreement' (2009) 76 U Chi L Rev 1215, 1224.
} 
case. ${ }^{77}$ Such correlations between legal controversy and the use of foreign law support our finding that significant numbers of apex judges cite opportunistically or to win extra-jurisdictional social reward-given no legally determined solution, non-legal criteria would come to the fore. In making this observation, we are careful to note that our finding is concerned only with the constitutional rights judgments of apex judges in which they would be ready to cite foreign law. The data offer no reason for thinking unselfconscious talk about right answers is rare-even in appellate courts. ${ }^{78}$

In principle, the survey's final question should have cast further light on the matter.

Question 19:

What is the main reason behind your use of domestic precedents?

- To indicate that you are taking a course that has been endorsed by respected professionals

- To help confirm whether your particular conclusion is on the right track

- To promote a sense of predictability of legal outcome

- As a source of ideas as to how best to resolve the case at hand

- To free up judicial resources by reducing the need for in depth consideration of the case at hand

- Other-please specify

The question was rather unpopular with respondents, with only 29 offering an answer. There was considerable disagreement with its underlying assumption; that apex courts are responsible for the effect of their previous decisions on any pending decision. Of those who answered, 11 judges indicated that the main reason behind their use of precedent was the promotion of a sense of predictability of legal outcome; seven indicated that their main use of precedent was as a source of ideas with which to resolve their cases; seven used precedent mainly to help confirm whether their conclusions were on the right track; and four used it mainly to indicate they were taking a course that has been endorsed by respected professionals. We may at least continue assuming that the promotion of legal certainty is a leading reason for judicial adherence to (domestic) precedents in apex courts.

\footnotetext{
77 See CL Ostberg et al, 'Attitudes, Precedents and Cultural Change: Explaining the Citations of Foreign Precedents by the Supreme Court of Canada' (2001) 34 Canadian J Pol Sci 377, 396, 'Citations to other than Canadian precedents grow as the number of concurring or dissenting opinions in a given case escalates.' See similarly, Smithey (n 30) 1200-1202 (South Africa and Canada); Calabresi and Zimdahl (n 30) 755, '[T]he [US] Court has tended to cite foreign law in some of [what the authors regard as] its most problematic opinions...'

78 There is empirical evidence of legal doctrine playing a causal role in US Supreme Court decision-making, see eg, H Gillman, The Constitution Besieged: The Rise and Demise of Lochner Era Police Powers Jurisprudence (Duke University Press, Chapel Hill, 1993); and M Richards and H Kritzer, 'Jurisprudential Regimes in Supreme Court Decision Making' (2002) 96 Am Pol Sci Rev 305.
} 


\section{CONCLUSION}

A general limitation to this study as an insight into the drivers of comparative legal argument is its focus on judges. Judges certainly seem a necessary element in the transnationalization of constitutional rights discourse. But the work of appellate trial lawyers is widely regarded as an important factor in a common law judge's reasoning, at least in its published form. ${ }^{79}$ The tactical thinking of such lawyers and judicial attitudes towards their work, as well as the impact of broader societal factors, ${ }^{80}$ merit serious consideration.

Nevertheless, what we have found suggests that the globalist school has correctly identified an interesting factor in judicial decision-making on constitutional rights; that, for many apex judges, foreign judges form a reference group on the resolution of such questions. Conversely, the data indicate that the globalist conception of judges citing foreign law as a source of persuasive authority may apply to only a minority of judicial comparativists. Citational opportunism and the aspiration to membership of an emerging international judicial 'guild' appear to be equally prevalent strands in attitudes towards the use of foreign law. The survey data accordingly appear to present a range of cases in which many or most apex judges do not regard themselves as pursuing the discovery of the legally correct answer. This is consistent with the findings of other empirical research into judicial comparison. Notwithstanding Dworkin's caution about the pitfalls of direct inquiry, the result is tension with his theory of legal objectivity.

${ }^{79}$ See eg Paterson (n 66).

${ }^{80}$ Charles Epp argues, plausibly, for the importance of a support infrastructure of publicly minded lawyers and grassroots organisations campaigning to push 'the rights agenda'; C Epp, The Rights Revolution: Lawyers, Activists and Supreme Courts in Comparative Perspective (University of Chicago Press, Chicago, 1998). 